\title{
Effectivity of Preovulation Phase Autologous Serum Application on Moderate-Severe Acne Vulgaris Patients
}

\author{
Nurhayati Edison $^{1}$, Safruddin Amin ${ }^{1}$, Khairuddin Djawad ${ }^{1}, \operatorname{Raden}_{\text {Satriono }}{ }^{2,3}$, Yohanes Widodo ${ }^{4}$, \\ Marianti A. Manggau ${ }^{5}$ \\ ${ }^{1}$ Department of Dermatology and Venereology, Medical Faculty, Hasanuddin University, Makassar, Indonesia \\ ${ }^{2}$ Department of Biostatistic, Faculty of Public Health, Hasanuddin University, Makassar, Indonesia \\ ${ }^{3}$ Department of Pediatric, Medical Faculty, Hasanuddin University, Makassar, Indonesia \\ ${ }^{4}$ Department of Dermatology and Venereology, Medical Faculty, Gadjah Mada University, Jogjakarta, Indonesia \\ ${ }^{5}$ Department of Pharmacy, Hasanuddin University, Makassar, Indonesia
}

Email address:

yethiedison85@gmail.com (N. Edison)

\section{To cite this article:}

Nurhayati Edison, Safruddin Amin, Khairuddin Djawad, Raden Satriono, Yohanes Widodo, Marianti A. Manggau. Effectivity of Preovulation Phase Autologous Serum Application on Moderate-Severe Acne Vulgaris Patients. American Journal of Clinical and Experimental Medicine. Vol. 4, No. 6, 2016, pp. 170-178. doi: 10.11648/j.ajcem.20160406.13

Received: September 16, 2016; Accepted: September 28, 2016; Published: November 10, 2016

\begin{abstract}
Acne vulgaris (AV) is the most common skin disease, including in Indonesia. This research aims to determine the effectivity of preovulation phase autologous serum application in patients with moderate-severe AV. This research was conducted in Makassar, South Sulawesi. Thirteen patient samples with moderate-severe AV who have met the inclusion criteria were taken from Dr. Wahidin Sudirohusodo General Hospital, Public Senior High School, and Medical Faculty of Hasanuddin University Laboratory. The method used is clinical trial. The examination was done by observing the clinical manifestations, sebum level using 815 sebumeter, and estradiol level examination. All patiens were given the same autologous serum treatment which is applied once a day every night and followed-up on day 21 and day 42 . The data were processed using paired $t$ test and Fisher's exact test. The result showed that there were improvements in clinical manifestation and decreased sebum level after autologous serum application $(\mathrm{p}<0.05)$ on day 21 compared to day 1 , on day 42 compared to day 21 , and day 42 compared to day 1. Preovulation estradiol level were higher than the estradiol level on menstruation or in lutheal phase $(\mathrm{p}<0.05)$. There were no significant relationship between routine activity, familial history, peanuts, chocolate, spicy and oily food consumption, wearing cosmetics, stress, and squeezing pimples (trauma) with number of acne lesion and sebum level $(p<0.05)$.
\end{abstract}

Keywords: Moderate to Severe Acne Vulgaris, Autologous Serum, Estradiol

\section{Introduction}

Acne vulgaris (AV) is the most common skin disease, including in Indonesia. Although AV doesn't endanger life, it is a common cosmetic problem in severe AV due to the scars inflicted, and not rarely became patients' psychological complaints on the social environment around them, even causing lack of confidence in such individuals. $[1,2]$ It is a chronic disease of the pilosebaceous unit characterized by comedones, papules, pustules, nodules, and scarring. Blackheads are the early signs of AV lesions, while papules and pustules are the result of inflammation, characterized by erythema and edema which can enlarge to form nodules. Acne vulgaris usually affects the face, chest, back, and upper arms. [3, 4]

The incidence are often found by dermatologists especially in adolescence and sometimes continues into adulthood. AV prevalence is about $85 \%$ for individuals aged 12 to 24 years. [5] In United States, AV affects about 40-50 million people each year, but women are more often affected than men. [6] The pathogenesis is not clearly known yet. Nonetheless, AV is generally a multifactorial disease characterized by follicular hyperkeratinization, increased sebaceous glands activities, hypercolonisation by Propionibacterium acnes (P. acnes), and inflammation. Various studies have shown the role of androgens in AV pathogenesis. Androgen hormones increases sebum production and follicular keratosis which is 
the key etiology of AV. Androgen hormones stimulate sebaceous glands (sebum) growth and differentiation. All external factors such as stress, smoking, alcohol and food, are interconnected to each other. $[1,7,8]$

There are wide varieties of $\mathrm{AV}$ therapeutic modalities, ranging from the use of topical until systemic treatment. The use of hormonal therapy for acne in women has a physiological rationale. There are also clinical evidence in the use of hormonal therapy in certain women with acne. Failure of treatment with standard regiment were commonly found in women. Failure on the use of systemic antibiotics is reported in 79 to $81 \%$ of women, and failures with isotretinoin ranged from 15 to $30 \%$. In the subgroup of young adult women, acne is a chronic problem, it can take up to 20 years. Chronic acne were often experienced treatment failure with standard regiment and is associated with bacterial resistance. All those factors became the basis for clinical usage of hormones in certain women with acne. [6,9]

Autologous serum is a serum obtained from the patient's own blood. The serum consists of blood liquid component which contains no cellular components and clotting factors. Those blood liquid components include serum electrolytes, hormones, proteins, growth factors, vitamins, and immunoglobulin. One of the autologous serum components is the estrogen hormone. Physiologically, we can find estrogen in women. Estrogen concentrations increased in the late follicular phase, estrogen concentrations in the serum will continue to increase until ovulation (approximately on day 13), after that the estrogen levels will go down and will rise again during lutheal phase. $[10,11,12]$

The main goal of hormonal therapy is to counteract the effects of androgens on the sebaceous glands. Drugs used for hormonal therapy can be divided into four groups, the first one is the usage of oral contraceptives. [6] Oral contraceptives generally contain estrogen (ethinyl estradiol) and progestin. Oral contraceptives reduce androgen effects by lowering the ovarian androgen production via inhibition of luteinizing hormone ( $\mathrm{LH})$ and follicle stimulating hormone (FSH). Secondary antiandrogen effect of oral contraception is the increased steroid hormone binding globulin which induced by estrogen, lowering circulating serum testosterone levels, causing decreased sebum production. [6, 9, 13] Estrogen also works through direct opposition to androgens in sebaceous glands, where androgen receptor found in the nucleus of the sebaceous glands, eccrine ducts, and papillary dermis. [6, 9, 12]

Based on those backgrounds, the authors are interested in conducting research that aims to determine the effectiveness of preovulation phase autologous serum usage in patients with moderate-severe AV.

\section{Material and Methods}

\subsection{Location and Research Time}

This research was conducted at the Dermato-Venerology Clinic of Dr. Wahidin Sudirohusodo General Hospital and its other hospital network, as well as senior high school (SMU) in Makassar City starting from September 2015 until April 2016.

\subsection{Design and Research Variables}

This research use the clinical trial study design with prospective pre- and post-treatment method. The research variables consist of: the independent variables (serum autologous, diet, stress, trauma, UV rays, genetic, cosmetics, pharmaceuticals), the dependent variables (clinical manifestations and sebum levels), and the intermediate variable (androgens, increased sebum production and follicular hyperkeratinisation, follicular obstructions, $P$. acnes colonization, and inflammation).

\subsection{Population and Sample}

The research population is the group of patients with moderate to severe acne vulgaris and patients who came to the Dermato-Venerology Clinic of Dr. Wahidin Sudirohusodo General Hospital, as well as senior high school (SMU) students. Research samples are the entire population who have met the inclusion criteria and didn't met the exclusion criteria. The total samples were 13 patients with acne vulgaris.

\subsection{Data Collection Methods}

Sebum level and clinical manifestations from 13 acne vulgaris patients who have met the inclusion criteria and didn't met the exclusion criteria were collected, and then we perform blood sampling (preovulation phase). Thirty cc (30 cc) blood samples were taken from medial cubital vein with antiseptic manner using vacutainer $25 \mathrm{G}$ needle inserted into the tube, and then the blood will be centrifuged for 10-15 minutes at $3000 \mathrm{rpm}$, in which the serum will be separated above, and will be stored in refrigerator with the temperature $-20^{\circ} \mathrm{C}$. The next examination is menstrual, preovulation, and luteal phase autologous serum every night. Sebum level and clinical manifestations will be measured again on day 21 and day 42 after the start of research.

\subsection{Data Analysis}

Data in this study will be proecssed using statistic software, SPSS version 21.0. All analysis results will be presented in tables with explanation. Statistical test used was paired t test and Fisher's exact test. The hypothesis will be accepted if the $\mathrm{p}$ value $<0.05$.

\section{Results}

Table 1. Sebum Level Comparison in Moderate-Severe AV Patients after Autologous Serum Application $\left(\mu \mathrm{g} / \mathrm{cm}^{2}\right)$.

\begin{tabular}{lll}
\hline Sebum level $\left(\boldsymbol{\mu g} / \mathbf{c m}^{\mathbf{2}}\right)$ & Mean \pm SD & p \\
\hline Sebum level day 1 & $601.08 \pm 212.509$ & $0.002^{\mathrm{a}}$ \\
Sebum level day 21 & $490.92 \pm 206.127$ & $0.000^{\mathrm{b}}$ \\
Sebum level day 42 & $383.38 \pm 158.128$ & $0.000^{\mathrm{c}}$ \\
\hline
\end{tabular}

Note: Paired t test (a) Serum level difference on day 21 compared to day 1. (b) Serum level difference on day 42 compared to day 21. (c) Serum level difference on day 42 compared to day 1 . 
In this study, we found that there was a significant sebum level difference in moderate-severe AV patients after autologous serum application which is significantly lower on day 21 compared to day $1(\mathrm{p}<0.05)$, sebum level day 42 compared to day $21(\mathrm{p}<0.05)$, and sebum level day 42 compared to day $1(\mathrm{p}<0.05)$ (Table 1$)$.
We also found that there's a significant clinical manifestation (lesion number) difference after autologous serum application which is significantly lower on day 21 compared to day $1(\mathrm{p}<0.05)$ (Figure 1,2 , and 3 ), sebum level day 42 compared to day $21(\mathrm{p}<0.05)$, and sebum level day 42 compared to day $1(\mathrm{p}<0.05)$ (Table 2$)$.

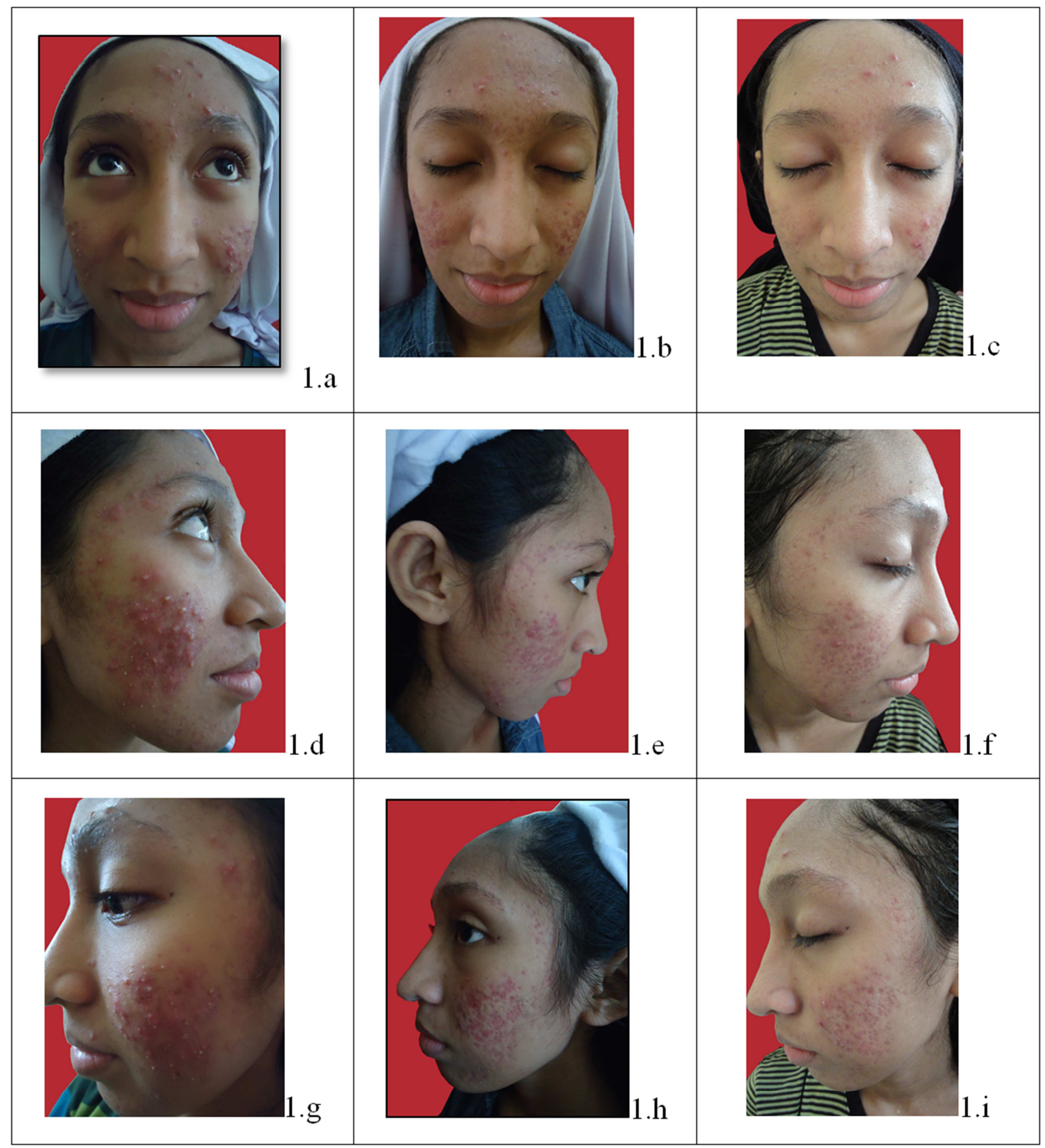

Figure 1. Patient 1. Improvement of clinical manifestation on day $1(a, d, g)$, day 21 (b,e,h), and $42(c, f, i)$. 


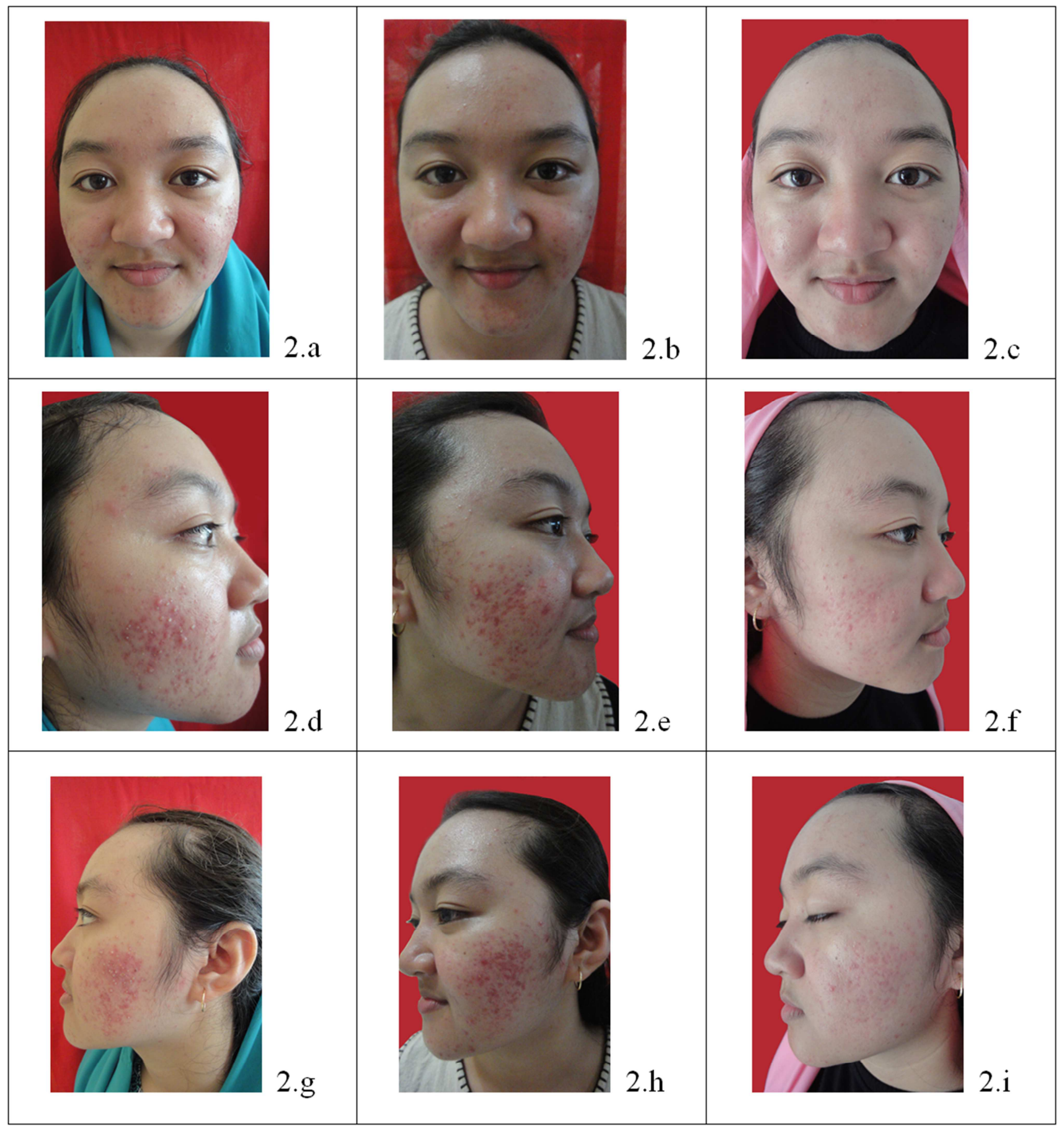

Figure 2. Patient 2. Improvement of clinical manifestation on day 1 (a,d,g), day 21 (b,e,h), and 42 (c,f,i).

Table 2. Clinical Manifestation (Lesion Number) Comparison in ModerateSevere AV Patients after Autologous Serum Application.

\begin{tabular}{lll}
\hline Clinical Manifestation (Lesion number) & Mean \pm SD & p \\
\hline Lesion number day 1 & $120.46 \pm 47.109$ & $0.007^{\mathrm{a}}$ \\
Lesion number day 21 & $73.15 \pm 41.267$ & $0.000^{\mathrm{b}}$ \\
Lesion number day 42 & $38.92 \pm 20.164$ & $0.000^{\mathrm{c}}$ \\
\hline
\end{tabular}

Note: Paired t test. (a) Lesion number difference on day 21 compared to day 1. (b) Lesion number difference on day 42 compared to day 21. (c) Lesion number difference on day 42 compared to day 1 .

There's a significant peovulation estradiol level difference compared to menstrual and luteal phase $(\mathrm{p}<0.05)$ (Table 3$)$.

Table 3. Preovulation Estradiol Level Comparison with Menstrual and Luteal Phase Estradiol Level $(\mu \mathrm{g} / \mathrm{ml})$.

\begin{tabular}{lll}
\hline Estradiol level $(\mathbf{p g} / \mathbf{m l})$ & Mean \pm SD & p \\
\hline Preovulation estradiol level & $514.08 \pm 84.674$ & \\
Menstrual estradiol level & $162.38 \pm 40.215$ & $0.000^{\mathrm{a}}$ \\
Lutela phase estradiol level & $247.15 \pm 84.674$ & $0.000^{\mathrm{b}}$ \\
\hline
\end{tabular}

Note: Paired t test. Normality test $\mathrm{p}<0.05$. (a) Preovulation and menstrual estradiol level difference. (b) Preovulation and lutheal phase estradiol level difference. 
Based on lesion number analysis, there were no significant relationship between routine activity, familial history, peanuts, chocolate, spicy and oily food consumption, wearing cosmetics, stress, and squeezing pimples (trauma) with number of acne lesion ( $\mathrm{p}>0.05)$ (Table 4).

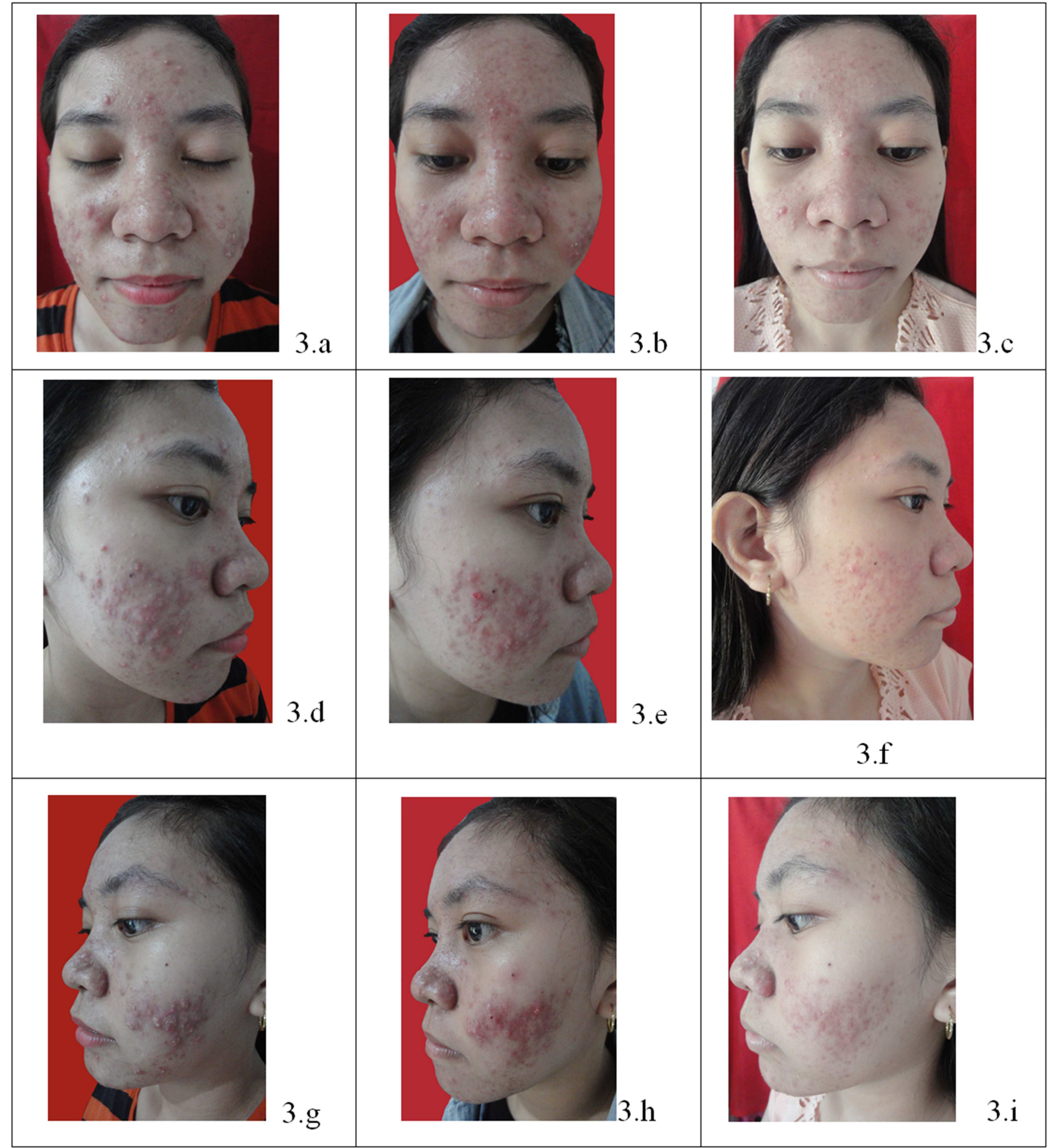

Figure 3. Patient 3. Improvement of clinical manifestation on day $1(a, d, g)$, day $21(b, e, h)$, and $42(c, f, i)$. 
Table 4. Relationship between routine activity, familial history, peanuts, chocolate, spicy and oily food consumption, wearing cosmetics, stress, and squeezing pimples (trauma) with number of acne lesion.

\begin{tabular}{|c|c|c|c|c|c|}
\hline & & \multicolumn{3}{|c|}{ Number of lesion } & \multirow{2}{*}{$\mathbf{p}$} \\
\hline & & a little & many & Total & \\
\hline \multicolumn{6}{|l|}{ Routine activity } \\
\hline \multirow{2}{*}{ Indoor activity } & $\mathrm{n}$ & 6 & 5 & 11 & \multirow{4}{*}{0.487} \\
\hline & $\%$ & $54,5 \%$ & $45,5 \%$ & $100,0 \%$ & \\
\hline \multirow{2}{*}{ Outdoor activity } & $\mathrm{n}$ & 2 & 0 & 2 & \\
\hline & $\%$ & $100,0 \%$ & $0,0 \%$ & $100,0 \%$ & \\
\hline \multicolumn{6}{|l|}{ Familial history } \\
\hline \multirow{2}{*}{ No } & $\mathrm{n}$ & 2 & 0 & 2 & \multirow{4}{*}{0.487} \\
\hline & $\%$ & $100,0 \%$ & $0,0 \%$ & $100,0 \%$ & \\
\hline \multirow{2}{*}{ Yes } & $\mathrm{n}$ & 6 & 5 & 13 & \\
\hline & $\%$ & $54,5 \%$ & $45,5 \%$ & $100,0 \%$ & \\
\hline \multicolumn{6}{|c|}{ Peanut consumption } \\
\hline \multirow{2}{*}{ Sometimes } & $\mathrm{n}$ & 3 & 4 & 7 & \multirow{4}{*}{0.266} \\
\hline & $\%$ & $42,9 \%$ & $57,1 \%$ & $100,0 \%$ & \\
\hline \multirow{2}{*}{ Often } & $\mathrm{n}$ & 5 & 1 & 6 & \\
\hline & $\%$ & $83,3 \%$ & $16,7 \%$ & $100,0 \%$ & \\
\hline \multicolumn{6}{|c|}{ Chocolate consumption } \\
\hline \multirow{2}{*}{ Sometimes } & $\mathrm{n}$ & 7 & 3 & 10 & \multirow{4}{*}{0.510} \\
\hline & $\%$ & $70,0 \%$ & $30,0 \%$ & $100,0 \%$ & \\
\hline \multirow{2}{*}{ Often } & $\mathrm{n}$ & 1 & 2 & 3 & \\
\hline & $\%$ & $33,3 \%$ & $66,7 \%$ & $100,0 \%$ & \\
\hline \multicolumn{6}{|c|}{ Spicy and oily food consumption } \\
\hline \multirow{2}{*}{ Sometimes } & $\mathrm{n}$ & 2 & 1 & 3 & \multirow{4}{*}{1.000} \\
\hline & $\%$ & $66,7 \%$ & $33,3 \%$ & $100,0 \%$ & \\
\hline \multirow{2}{*}{ Often } & $\mathrm{n}$ & 6 & 4 & 10 & \\
\hline & $\%$ & $60,0 \%$ & $40,0 \%$ & $100,0 \%$ & \\
\hline \multicolumn{6}{|c|}{ Wearing cosmetics } \\
\hline \multirow{2}{*}{ No } & $\mathrm{n}$ & 3 & 0 & 3 & \multirow{4}{*}{0.231} \\
\hline & $\%$ & $100,0 \%$ & $0,0 \%$ & $100,0 \%$ & \\
\hline Yes & $\mathrm{n}$ & 5 & 5 & 10 & \\
\hline 16 & $\%$ & $50,0 \%$ & $50,0 \%$ & $100,0 \%$ & \\
\hline Stress & & & & & \\
\hline $\mathrm{No}$ & $\mathrm{n}$ & 3 & 3 & 6 & \\
\hline ivo & $\%$ & $50,0 \%$ & $50,0 \%$ & $100,0 \%$ & 0.592 \\
\hline Yes & $\mathrm{n}$ & 5 & 2 & 7 & \\
\hline res & $\%$ & $71,4 \%$ & $28,6 \%$ & $100,0 \%$ & \\
\hline Squeezing pimple & & & & & \\
\hline No & $\mathrm{n}$ & 1 & 2 & 3 & \\
\hline 100 & $\%$ & $33,3 \%$ & $66,7 \%$ & $100,0 \%$ & 0.510 \\
\hline Yes & $\mathrm{n}$ & 7 & 3 & 10 & \\
\hline 100 & $\%$ & $70,0 \%$ & $30,0 \%$ & $100,0 \%$ & \\
\hline
\end{tabular}

Fisher's exact test, $\mathrm{p}<0.05$.

There were also no significant relationship between routine activity, familial history, peanuts, chocolate, spicy and oily food consumption, wearing cosmetics, stress, and squeezing pimples (trauma) with sebum level $(\mathrm{p}>0.05)($ Table 5). 
Table 5. Relationship between routine activity, familial history, peanuts, chocolate, spicy and oily food consumption, wearing cosmetics, stress, and squeezing pimples (trauma) with sebum level.

\begin{tabular}{|c|c|c|c|c|c|}
\hline & & \multicolumn{3}{|c|}{ Sebum level } & \multirow[b]{2}{*}{$\mathbf{p}$} \\
\hline & & a little & many & Total & \\
\hline \multicolumn{6}{|l|}{ Routine activity } \\
\hline Indoor activity & $\mathrm{n}$ & 5 & 6 & 11 & \multirow{4}{*}{1.000} \\
\hline & $\%$ & $45,5 \%$ & $54,5 \%$ & $100,0 \%$ & \\
\hline Outdoor activity & $\mathrm{n}$ & 1 & 1 & 2 & \\
\hline \multicolumn{4}{|l|}{ Familial history } & $100,0 \%$ & \\
\hline No & $\mathrm{n}$ & 2 & 0 & 2 & \multirow{4}{*}{0.192} \\
\hline No & $\%$ & $100,0 \%$ & $0,0 \%$ & $100,0 \%$ & \\
\hline & $\mathrm{n}$ & 4 & 7 & 11 & \\
\hline Yes & $\%$ & $36,4 \%$ & $63,6 \%$ & $100,0 \%$ & \\
\hline \multicolumn{6}{|c|}{ Peanut consumption } \\
\hline Sometimes & $\mathrm{n}$ & 4 & 3 & 7 & \multirow{4}{*}{0.592} \\
\hline sometrmes & $\%$ & $57,1 \%$ & $42,9 \%$ & $100,0 \%$ & \\
\hline Often & $\mathrm{n}$ & 2 & 4 & 6 & \\
\hline Often & $\%$ & $33,3 \%$ & $66,7 \%$ & $100,0 \%$ & \\
\hline \multicolumn{6}{|c|}{ Chocolate consumption } \\
\hline Sometimes & $\mathrm{n}$ & 6 & 4 & 10 & \multirow{4}{*}{0.192} \\
\hline sometnimes & $\%$ & $60,0 \%$ & $40,0 \%$ & $100,0 \%$ & \\
\hline Often & $\mathrm{n}$ & 0 & 3 & 3 & \\
\hline Onen & $\%$ & $0,0 \%$ & $100,0 \%$ & $100,0 \%$ & \\
\hline \multicolumn{6}{|c|}{ Spicy and oily food consumption } \\
\hline Sometimes & $\mathrm{n}$ & 1 & 2 & 3 & \multirow{4}{*}{1.000} \\
\hline & $\%$ & $33,3 \%$ & $66,7 \%$ & $100,0 \%$ & \\
\hline Often & $\mathrm{n}$ & 5 & 5 & 10 & \\
\hline Utten & $\%$ & $50,0 \%$ & $50,0 \%$ & $100,0 \%$ & \\
\hline \multicolumn{6}{|c|}{ Wearing cosmetics } \\
\hline No & $\mathrm{n}$ & 1 & 2 & 3 & \multirow{4}{*}{1.000} \\
\hline & $\%$ & $33,3 \%$ & $66,7 \%$ & $100,0 \%$ & \\
\hline Yes & $\mathrm{n}$ & 5 & 5 & 10 & \\
\hline yes & $\%$ & $50,0 \%$ & $50,0 \%$ & $100,0 \%$ & \\
\hline \multicolumn{6}{|l|}{ Stress } \\
\hline No & $\mathrm{n}$ & 2 & 4 & 6 & \multirow{4}{*}{0.592} \\
\hline No & $\%$ & $33,3 \%$ & $66,7 \%$ & $100,0 \%$ & \\
\hline Yes & $\mathrm{n}$ & 4 & 3 & 7 & \\
\hline yes & $\%$ & $57,1 \%$ & $42,9 \%$ & $100,0 \%$ & \\
\hline \multicolumn{6}{|c|}{ Squeezing pimples (Trauma) } \\
\hline No & $\mathrm{n}$ & 3 & 0 & 3 & \multirow{4}{*}{0.070} \\
\hline NO & $\%$ & $100,0 \%$ & $0,0 \%$ & $100,0 \%$ & \\
\hline Yes & $\mathrm{n}$ & 3 & 7 & 10 & \\
\hline Yes & $\%$ & $30,0 \%$ & $70,0 \%$ & $100,0 \%$ & \\
\hline
\end{tabular}

Fisher's exact test, $\mathrm{p}<0.05$.

\section{Discussion}

This research shows that there were improvements in clinical manifestation and sebum level in patients with moderate-severe AV after autologous serum aplication. Preovulation estradiol level were higher than estradiol level on menstrual or lutheal phase $(p<0.05)$. There's also no significant relationship between routine activity, familial history, peanuts, chocolate, spicy and oily food consumption, wearing cosmetics, stress, and squeezing pimples (trauma) with number of acne lesion and sebum level $(\mathrm{p}<0.05)$.

Acne vulgaris is a disease of the pilosebaceous unit that is commonly found in adolescence and can persist into adulthood. The average prevalence in adolescent is estimated around 70 to $87 \%$, which is characterized by comedones, papules, pustules, and nodules. [14, 15] In acne pathogenesis, androgens have a very important role. Generally, acne vulgaris will not develop in the absence of androgen hormone. People who are not sensitive to androgens would not suffer from acne because they do not produce sebum; and a high androgen state will accompanied by acne. [15] While androgen role is very important, the process involved is quite complex. Variations in clinical response to androgens in some patients indicate that local factors and circulating factors other than the androgen also influence acne development. In addition, "post-androgen" phase is needed in the full development of inflammatoric acne lesions. This includes factors that affect the adhesion of keratinocytes, the development of bacteria Propionibacterium acnes, and inflammatoric mediators. However, without the initial effects of androgen, the next stages of development to become acne will not occur; a concept which underlines the potential of hormonal therapy for acne. $[9,14]$

In this study, there is a significant reduction in the amount 
of sebum on day 21 and on day 42 compared to day 1 after administration of autologous serum, in which we obtain value $\mathrm{p}<0.05$. Sebum plays an important role in the process, especially in the acnegenesis comedogenicity process, where the data showed that sebum production levels were higher in patients with severe AV. [16] In AV patients, the size of sebaceous follicles and lobules number in each sebaceous glands increases. Sebaceous glands will begin to swell in the presence of androgen hormone stimulation, leading to increased sebum excretion. Sebum will continually synthesized and secreted by the sebaceous glands to the skin surface through the hair follicle pores. Imbalance between sebum production and secretion capability will lead to sebum accumulation in hair follicle resulting in the formation of microcomedone which would later become inflammatory lesions. [16, 17] Androgen receptors were found in the nucleus of the sebaceous glands, sebaceous duct keratinocytes, eccrine duct follicular and papillary dermis. [18] One of the autologous serum content obtained were estrogen hormone. Estrogen works through several mechanisms, which one direct is opposition to androgens in sebaceous glands. [13, 19]

Based on this research, the number of lesions on day 21 and on day 42 was significantly reduced when compared to day 1 . This shows the influence of application of autologous serum to repair acne vulgaris lesions. Autologous serum contains electrolytes, hormones, proteins, growth factors, vitamins and immunoglobulin. One of the hormones found in autologous serum is the estrogen hormone. Estrogen consists of estradiol, estrone, and estriol. Estradiol is the primary active estrogen. [20] At preovulation phase, estradiol levels in blood will increase. Estradiol level during preovulation phase were higher than in menstrual and luteal phase. $[10,11$, 12] From this study, we also found that autologous serum applicant who have high estradiol levels can reduce the severity of acne lesions. It can be caused by the estrogen hormone that is in opposition to the androgen hormone that there is a decrease in sebum levels. Decreased sebum levels will reduce the growth of $P$. acnes on the developing acne lesions. $[19,13]$

Autologous serum usage in dermatology for AV treatment have obtain meaningful results, it is presumably because estradiol level inside the autologous serum being applied were high, so there is a reduction in sebum production caused by estrogen which also works through direct opposition to androgens in sebaceous glands. Autologous serum was also used in ophthalmology, such as eye drops for the treatment of keratoconjunctivitis sicca. [21] Research conducted by Ilham (2011) using rats that were divided into 5 groups which received treatment using autologous serum eye drops with various concentrations showed that the autologous serum has an antibacterial effect because it contains some antibacterial agents including immunoglobulins, lysozyme, and complement which caused lysis of the bacteria and provide bacteriostatic effect, whereas the anti-inflammatory effects of the autologous serum were based on the epiteliotrophic factors (epidermal growth factor, transforming growth factor
$\mathrm{B}$, fibronectin, and vitamin $\mathrm{A}$ ) and neutrophilic (substance $\mathrm{P}$, nerve growth factor) contained in the serum. [20, 22, 23]

In this study, preovulation estradiol levels were higher than estradiol levels during menstruation or during the luteal phase. Based on statistic test, the $p$ value was $<0.05$. It is according to the literature stating that the production of estradiol will continue to increase until ovulation time, after that the estradiol levels will fell during ovulation. Estradiol level was highest in preovulation phase, and was lowest during menstruation phase, it will then rise again during luteal phase but not as high during the preovulation phase. $[10,11]$

In this study, we didn't find any side effect during autologous serum application. There was no control group (placebo) in this study, so further research with control group is needed for better results.

\section{Conclusions and Recommendations}

Researchers concluded that there were clinical manifestations improvements in patients with moderate-severe AV after the autologous serum application. There was a decreased sebum levels in patients with moderate-severe AV after the autologous serum application. Researchers suggested that autologous serum can be used as a therapeutic option in moderate to severe acne vulgaris, and further research with control group (placebo) is needed to exclude the risk factors that influence the autologous serum effectivity.

\section{References}

[1] Anwar, A. I, Tata Laksana Akne Vulgaris Makassar. Dua Satu Pree, 2013.

[2] Bowe, W. P. \& Shalita, A. R, Introduction: Epidemiology, Cost, And Psychosocial Implications. In: Shalita, A. R., Rosso, J. Q. D. \& Webster, G. F. (Eds.) Acne Vulgaris. New York: Informa Healhcare. 2011.

[3] Zaenglein, A. L., Graber, E. M. \& Thiboutot, D. M, Acne Vulgaris And Acneiform Eruptions. In: Goldsmith, L. A., Katz, S. I., Gilchrest, B. A., Paller, A. S., Leffell, D. J. \& Wolff, K. (Eds.) Fitzpatrick's Dermatology In General Medicine. 8 Th Ed. New York: Mc Graw Hill. 2012.

[4] James, W. D., Berger, T. G. \& Elston, D. M, Andrews' Diseases Of The Skin Clinical Dermatology "Acne" Philadelphia, Saudres Elsevier. 2006.

[5] Tahir, C. M, Pathogenesis Of Acne Vulgaris: Simplified. $J$ Pakistan Association Of Dermatologists, 2010. 20: p. 93-7

[6] George, R., Clarke, S. \& Thiboutot, D, Hormonal Therapy For Acne. Semin Cutan Med Surg, 2008: 27: p. 188-96

[7] Knor, T, The Pathogenesis Of Acne. Acta Dermatovenerol Croat, 2005. 13: p. 44-9.

[8] Balachandrudu, B., Niveditadevi, V. \& Rani, T. P, Hormon Pathogenesis Of Acne- Simplified. Inter J Scient Study, 2015. 3: p. 183-185. 
[9] Shaw, J. C, Acne Efffect Of Hormones On Pathogenesis And Management. Am J Clin Dermatol, 2002. 3: p. 571-578.

[10] Hanafiah, M. J, Haid Dan Siklusnya, In: Wiknjosastro, H., Saifuddin, A. B. \& Rachimhadhi, T. (Eds.) Ilmu Kandungan Tridasa Printer, Jakarta: Yayasan Bima Pustaka Sarwono Prawirohardji. 2007.

[11] Jacoeb, T. Z, Endokrinologi Reproduksi Pada Wanita, In: Wiknjosastro, H., Saifuddin, A. B. \& Rachimhadhi, T. (Eds.) Ilmu Kandungan Tridasa Printer, Jakarta: Yayasan Bima Pustaka Sarwono Prawirohardji. 2007.

[12] Gruber, C. J., Tschugguel, W., Schneeberger, C. \& Huber, J. C, Production And Actions Of Estrogens. N Engl J Med, 2002. 346: p. 340-52.

[13] Thiboutot, D. \& Chen, W, Update And Future Of Hormonal Therapy. Dermatol, 2003. 206: p. 57-67.

[14] Ebede, T. L., Arch, E. L. \& Berson, D, Hormonal Treatment Of Acne In Women. J Clin Aesthetic Dermatol, 2009. 12: p. 16-22.

[15] Lakshmi, C, Hormone Therapy In Acne. Ind J DermatolVenereo And Lepro, 2013. 79: p. 322-36.

[16] Baumann, M, Acne. In: Bauman L \& Wwisberg E (Eds). Cosmetic dermatology principles and practice. New York,
The McGraw-Hill Companies. 2002.

[17] Gollnick, H. \& Cunliffe, W, Management Of Acne A Report From A Global Alliance To Improve. Jaad, 2003. 49: p. S1-5.

[18] Preneau S, Dreno B, Female acne - a different subtype of teenager acne? JEADV, 2011. 26: p. 277-82.

[19] Harper, J. C, Hormonal Therapy For Acne Using Oral Contraceptive Pills. Semin Cutan Med Surg, 2005. 24: p. 103106.

[20] Geerling, G., MacLennan, S., Hartwig, D, Autologous serum eye drops for ocular surface disorders. Br J Ophthalmol, 2004. 88: p. 1467-74.

[21] Poon, A. C., Geerling, G., Dart, J. K., Fraenkel, G. E., Daniels, J. T, Autologous serum eyedrops for dry eyes and epithelial defects: clinical and in vitro toxicity studies. Br J Ophthalmol, 2001. 85 (10): p. 1188-97.

[22] Ilham, Pengujian tetes mata serum autolog sebagai antibakteri dan inflamasi pada penyakit permukaan okuler. Makassar, Universitas Hasanuddin. 2011.

[23] Tsubota, K., Goto, E., Fujita, H., Ono, M., Inoue, H., Saito, I., et al, Treatment of dry eye by autlogous serum application in Sjogren's syndrome. Br J Dermatol, 1999. 83: p. 390-5. 